\title{
Peningkatan Pengawasan Penyelenggaraan Pelayanan Publik Melalui Saluran Ombudsman di Desa Tuapejat, Kecamatan Sipora Utara, Kabupaten Kepulauan Mentawai
}

\author{
Muhammad Ichsan Kabullah, Ria Ariany, Yoserizal, dan Wewen Kusumi Rahayu \\ Fakultas Ilmu Sosial dan Ilmu Politik, Universitas Andalas, Kampus Limau Manis, Padang, 25163. Indonesia \\ E-mail: muhammadichsankabullah@soc.unand.ac.id
}

Keywords:

control,

Ombudsman,

public service,

Tuapejat

Kata Kunci:

Ombudsman,

pengawasan,

pelayanan publik,

Tuapejat

\begin{abstract}
The existence of public services in local governments is facing a severe problem. The implementation of regional autonomy has not been able to encourage the birth of services quickly, cheaply, accountably, and transparently. This is compounded by a slow service culture in the bureaucracy. As a result, the essence of government as a public servant is lost. In that sense, the Ombudsman established since 2008. Based on Law Number 37 of 2008 about the Ombudsman of the Republic of Indonesia, the Ombudsman has a purpose as a bridge between the government and the community in improving public services. In its development, the existence of the Ombudsman is present in all regions including West Sumatra Province. However, there are still many people who have not known this institution. This article describes an improvement for public on service delivery through the Ombudsman in Tuapejat Village. The village, located in the Mentawai Islands Regency, is an isolated area in West Sumatra. With the presence of the Ombudsman, the public services can improve in the village eventough the geographical constraints faced. From the activities carried out, it can be seen that the public is not familiar with the Ombudsman. Community has been weak in control of public service delivery. At the same time, it also caused by permissive culture. Therefore, an ombudsman is important in increasing public participation in carrying out service supervision in the bureaucracy.
\end{abstract}
ABSTRAK
Tidak dapat dipungkiri, penyelenggaraan pelayanan publik secara maksimal pada pemerintahan daerah masih menjadi pekerjaan rumah yang belum terselesaikan. Pelaksanaan otonomi daerah belum mampu mendorong lahirnya pelayananan secara cepat, murah, akuntabel, dan transparan. Hal ini diperparah dengan kultur pelayanan yang lamban di birokrasi. Akibatnya esensi pemerintah sebagai pelayan masyarakat menjadi hilang. Disinilah titik awal lahirnya Ombudsman. Melalui UU Nomor 37 Tahun 2008 tentang Ombudsman Republik Indonesia, Ombudsman diharapkan hadir untuk berperan nyata sebagai jembatan antara pemerintah dan masyarakat dalam peningkatan pelayanan publik. Dalam perkembangannya, keberadaan Ombudsman hadir di daerah seperti Provinsi Sumatera Barat. Akan tetapi, masih banyak masyarakat yang belum memanfaatkan lembaga ini secara maksimal. Artikel ini berupaya menggambarkan upaya peningkatan fungsi pengawasan penyelenggaraan pelayanan publik melalui Ombudsman di Desa Tuapejat. Desa yang terletak di Kabupaten Kepulauan Mentawai ini merupakan salah satu daerah yang masih terisolir di Sumatera Barat. Dengan hadirnya Ombudsman, diharapkan pelayanan publik di desa tersebut dapat meningkat 
ditengah kendala geografis yang dihadapi. Dari kegiatan yang dilakukan maka dapat dilihat masyarakat belum begitu mengenal Ombudsman. Partisipasi masyarakat dalam pengawasan penyelenggaraan pelayanan publik yang selama ini lemah juga diakibatkan dengan kultur permisif. Oleh karena itu, keberadaan ombudsman dirasakan penting dalam meningkatkan partisipasi masyarakat dalam menjalankan pengawasan pelayanan di birokrasi.

\section{PENDAHULUAN}

Dalam kurun waktu dua dekade terakhir pasca reformasi, terdapat berbagai upaya penguatan peran serta masyarakat dalam peningkatan penyelenggaraan pelayanan publik di daerah. Hal ini sangat penting dilakukan ketika itu karena terdapat perubahan cara pandang masyarakat dalam melihat posisi pemerintah daerah yang pada awalnya pemerintah hadir sebagai instrumen penguasa menancapkan pengaruhnya ke tengah masyarakat menjadi instrumen publik yang hadir untuk melayani masyarakat. Perubahan cara pandang ini membuat Dewan Perwakilan Rakyat Daerah (DPRD) sebagai representasi rakyat memiliki pengaruh yang signifikan terhadap pemerintah daerah dalam pengawasan pelayanan publik. Melalui UU No. 22 Tahun 1999 tentang Pemerintah Daerah, DPRD diharapkan mampu menjalankan fungsi kontrol terhadap pemerintah daerah secara maksimal sehingga masyarakat merasa terwakili partisipasinya. Realita yang terjadi ketika itu, pergeseran ini lebih didominasi dengan munculnya praktik abuse of power oleh DPRD karena bargaining position yang terlalu kuat terhadap eksekutif. Akibatnya esensi akuntabilitas penyelenggaraan pelayanan publik oleh pemerintahan daerah menjadi hilang.

Menyadari hal tersebut, peningkatan pengawasan penyelenggaraan pelayanan publik di daerah bergeser kepada Badan Pemeriksa Keuangan (BPK) dan Badan Pengawasan Keuangan dan Pembangunan (BPKP). Pergeseran ini dianggap lebih independen karena pengawasan dilakukan secara objektif dan meminimalisir kepentingan yang bersifat politis. BPK contohnya memberikan opini penilaian terhadap tata kelola keuangan dan kinerja suatu lembaga negara termasuk pemerintah daerah. Sejalan dengan BPK, BPKP juga memiliki fungsi pengawasan keuangan akan tetapi lebih berupa pendampingan apabila mendapatkan temuan di pemerintah daerah. Meskipun demikian, perlu dikritisi bahwasannya peran BPK dan BPKP dalam pengawasan pelayanan publik sangatlah terbatas karena hanya terpaku kepada audit keuangan semata. Hal ini ditandai dengan tidak adanya hubungan yang kuat didapatkannya penilaian Opini Wajar Tanpa Pengecualian (WTP) oleh suatu pemerintah daerah dengan meningkatnya penyelengaraan pelayanan publik.

Dalam perkembangannya, peningkatan peran serta masyarakat dalam penyelenggaraan pelayanan publik diatur melalui pembentukan lembaga negara baru yang otonom dan independen yakni Ombudsman. Sebagai pengejewantahan UU Nomor 37 Tahun 2008 tentang Ombudsman Republik Indonesia, ombudsman berkedudukan di pusat dan daerah yang dalam tugasnya bertanggung jawab mewakili masyarakat dalam mengawasi pelayanan publik. Hal ini sesuai pada fungsi Ombudsman di pasal 6 UU Nomor 37 Tahun 2008 yakni mengawasi penyelenggaraan pelayanan publik yang diselenggarakan oleh penyelenggara negara dan pemerintahan baik di pusat maupun di daerah termasuk oleh BUMN, BUMD, BHMN serta badan swasta atau perseorangan yang diberi tugas menyelenggarakan pelayanan publik tertentu. Keberadaan ombudsman sangatlah penting sebagai salah satu aktor pelengkap yang menutup kelemahan absurdnya mekanisme pengawasan pelayanan publik yang berjalan selama ini. Mulgan (2000) menjelaskan tidak ada satu lembaga yang mampu menggaransi terciptanya akuntabilitas yang efektif. Oleh karena itu, keterlibatan multi aktor seperti Ombudsman dalam pengawasan pelayanan publik sesungguhnya mencerminkan adanya peran serta masyarakat yang kuat dalam mendorong good local governance.

Sifatnya yang independen dan legal membuat publik bisa lebih memilih ombudsman untuk menyuarakan ketidakpuasan dan praktik penyimpangan pada penyelenggaraan pemerintahan di 
daerah. Jika dulu penyampaian public complaint hanya diarahkan kepada lembaga yang memiliki ruang gerak terbatas seperti Yayasan Lembaga Konsumen Indonesia (YLKI) maka kini diharapkan dengan kehadiran ombudsman daerah bisa memberi solusi-solusi konkrit. Lebih lanjut, setiap ombudsman daerah yang baru terbentuk termasuk di Provinsi Sumatera Barat harus terus melakukan sosialisasi keberadaan lembaga, membentuk jaringan kelompok masyarakat, serta menetapkan agenda apa yang hendak dijadikan sebagai isu prioritas. Penentuan akomodasi isu prioritas sepatutnya disesuaikan dengan konteks struktur sosial budaya dan permasalahan yang berkembang ditengah masyarakat. Identifikasi ini harus jelas karena akan merepresentasikan karakteristik lembaga itu sendiri. Tanpa adanya kekhasan tersebut maka ombudsman daerah bisa saja masih dalam kegamangan.

Untuk konteks di Provinsi Sumatera Barat sendiri, meskipun UU telah mengatur keberadaan ombudsman, masih banyak masyarakat yang belum memanfaatkan pengaduan pelayanan publik melalui ombudsman itu sendiri. Berdasarkan Laporan Tahunan Ombudsman Republik Indonesia Perwakilan Provinsi Sumatera Barat (2017), terdapat 855 pengaduan masyarakat yang masuk ke Ombudsman Provinsi Sumatera Barat dalam kurun waktu 2015 sampai 2017. Adapun rincian jumlah pengaduan tersebut berdasarkan laporan adalah sebagai berikut:

Tabel 1. Jumlah Laporan Mayarakat Berdasarkan Asal Daerah Pelapor Tahun 2015-2017

\begin{tabular}{|c|c|c|c|c|}
\hline \multirow[t]{2}{*}{ No } & \multirow[t]{2}{*}{ Kabupaten/Kota } & \multicolumn{3}{|c|}{ Tahun } \\
\hline & & 2015 & 2016 & 2017 \\
\hline 1 & Kabupaten Agam & 5 & 9 & 5 \\
\hline 2 & Kabupaten Dharmasraya & 0 & 3 & 1 \\
\hline 3 & Kabupaten Kepulauan Mentawai & 1 & 1 & 1 \\
\hline 4 & Kabupaten Lima Puluh Kota & 5 & 5 & 0 \\
\hline 5 & Kabupaten Padang Pariaman & 5 & 10 & 2 \\
\hline 6 & Kabupaten Pasaman & 0 & 2 & 0 \\
\hline 7 & Kabupaten Pasaman Barat & 6 & 10 & 4 \\
\hline 8 & Kabupaten Pesisir Selatan & 9 & 10 & 6 \\
\hline 9 & Kabupaten Sijunjung & 0 & 1 & 0 \\
\hline 10 & Kabupaten Solok & 4 & 7 & 6 \\
\hline 11 & Kabupaten Solok Selatan & 1 & 6 & 2 \\
\hline 12 & Kabupaten Tanah Datar & 6 & 1 & 7 \\
\hline 13 & Kota Bukittinggi & 4 & 3 & 2 \\
\hline 14 & Kota Padang & 203 & 259 & 193 \\
\hline 15 & Kota Padang Panjang & 1 & 3 & 0 \\
\hline 16 & Kota Pariaman & 5 & 3 & 1 \\
\hline 17 & Kota Payakumbuh & 6 & 3 & 1 \\
\hline 18 & Kota Sawahlunto & 3 & 2 & 0 \\
\hline 19 & Kota Solok & 2 & 1 & 0 \\
\hline \multirow[t]{2}{*}{20} & Di Luar Sumatera Barat & 4 & 11 & 3 \\
\hline & Jumlah & 271 & 350 & 234 \\
\hline
\end{tabular}

Sumber: (Devina, 2018)

Dari data tersebut maka terlihat antusiasme masyarakat untuk terlibat aktif dalam pengawasan pelayanan publik sangat tinggi. Akan tetapi, dari total 855 pengaduan tersebut di dominasi pengaduan dari Kota Padang saja. Padahal rentang tugas ombudsman meliputi seluruh 
wilayah yang ada di Provinsi Sumatera Barat. Beberapa daerah yang perlu mendapat perhatian serius terkait rendahnya pengaduan yang masuk ke Ombudsman adalah Kabupaten Kepulauan Mentawai.

Rendahnya jumlah pengaduan dari Kabupaten Kepulauan Mentawai menandakan masih lemahnya pengawasan masyarakat dalam penyelenggaraan pelayanan publik terhadap pemerintah daerah. Padahal peran serta masyarakat sangatlah penting apabila mendapat ada dukungan nyata melalui partisipasi masyarakat. Dengan demikian, perlu kiranya untuk mendorong masyarakat agar berperan aktif dalam melakukan pengawasan pelayanan publik. Hal ini mengingat posisi masyarakat sebagai objek sebagai penerima manfaat atas pemberian pelayanan yang diberikan.

Oleh karena itu diperlukan kolaborasi nyata antara komunitas yang ada dimasyarakat. Kolaborasi tersebut diperlukan dalam rangka meningkatkan pemahaman masyarakat ditingkat terendah atas hak-hak pelayanan serta mekanisme pengaduan dan menyampaikan informasi jika menghadapi permasalahan-permasalahan yang timbul. Untuk itu, sebagai rangkaian kegiatan mendorong partisipasi masyarakat dalam pengawasan penyelenggaraan pelayanan publik maka diperlukan pelatihan peningkatan kapasitas masyarakat/ komunitas dalam menggunakan sarana pengaduan dan pelaporan dugaan mal administrasi oleh pemerintah daerah. Untuk itu maka kegiatan pengabdian yang akan kami lakukan akan berlangsung pada unit pemerintah terendah yakni Desa dengan alasan di tingkatan inilah yang merasakan langsung dampak pelayanan publik. Oleh karenanya, pengenalan dan pemanfaatan ombusdsman merupakan modal dasar yang sangat baik untuk melakukan kegiatan penguatan kapasitas masyarakat dalam pengunaan pengaduan pelayanan publik dalam penyelenggaraan pemerintahan.

Berangkat dari hal tersebut, maka penting kiranya memberikan ruang lebih besar kepada masyarakat untuk terlibat dalam pengawasan pelayanan publik melalui ombudsman. Apalagi hal tersebut sangat dimungkinkan dengan kondisi negara yang sangat demokratis dimana masyarakat dapat menyuarakan aspirasinya sebebas mungkin. Permasalahan yang timbul kemudian adalah peran serta masyarakat untuk memanfaatkan ombudsman sebagai sarana pengaduan pelayanan publik masih dapat dikatakan minim sebagaimana yang tampak di Kabupaten Kepulauan Mentawai. Adanya kecenderungan kultur permisif ketika berhadapan dengan penyelenggara pemerintah (Nordholt \& Klinken, 2007; Tidey, 2012) membuat perlu terobosan yang lebih nyata untuk mendorong masyarakat lebih berdaya. Disinilah pentingnya untuk memberikan pelatihan penguatan kapasitas masyarakat berbasis komunitas pada level pemerintah terendah yakni desa. Dengan memperkuat komunitas yang dilatih maka diharapkan tumbuh rasa kritis ditengah masyarakat. Disamping itu, komunitas tadi diharapkan juga menginspirasi anggota disetiap basis komunitasnya agar bersama pemerintah turut mendorong penyelenggaraan pemerintahan yang transparan dan akuntabel. Untuk itu, kami mengambil Desa Tuapejat, Kecamatan Sipora Utara, Kabupaten Kepulauan Mentawai, dalam kegiatan pengabdian ini.

\section{METODE}

Pencegahan terhadap mal administrasi dalam penyelenggaraan pelayanan publik oleh pemerintah tentu bukan hal yang mudah untuk dilakukan. Dibutuhkan rencana aksi dan advokasi yang lebih terintegrasi dengan melibatkan peran serta masyarakat sebagai representasi partisipasi publik. Dengan memberikan ruang kepada masyarakat dapat menjadi tanda komitmen pemerintah daerah untuk bersama-sama melakukan peningkatan pelayanan publik. Hal ini dapat dilakukan mulai dari tingkat pemerintahan terendah yakni desa. Berangkat dari hal tersebut maka langkah-langkah yang dilakukan dalam kegiatan pengabdian ini adalah sebagai berikut: 
1. Pengenalan pola perilaku mal administrasi dalam penyelenggaraan pelayanan pemerintahan

Identifikasi perilaku mal administrasi seperti korupsi, penundaan pelayanan, dan lain-lain sebagai behavior problem tentu membutuhkan sensifitas yang baik dari publik. Kultur permisif dan acuh terhadap persoalan mal administrasi dalam lingkungan birokrasi membuat penyelenggara pemerintah tidak responsif terhadap perubahan karena dianggap suatu perilaku normal keseharian yang mudah ditemui. Oleh karena itu, maka pada tahapan ini akan dilakukan identifikasi titik-titik yang rentan terhadap korupsi pada sektor pelayanan publik melalui uraian permasalahan dari para peserta atas apa yang pernah mereka alami ketika berhadapan dengan birokrasi. Peserta juga akan mendapatkan simulasi terhadap persoalan dalam penyelenggaraan pelayanan publik agar memiliki pemahaman dasar tentang korupsi, pungli, gratifikasi, suap dan sejenisnya.

\section{Pengenalan Ombusman}

Pada tahapan ini peserta pengabdian akan diperkenalkan ombudsman sebagai lembaga negara yang berwenang menerima dan menindaklanjuti pengaduan masyarakat dalam penyelenggaraan pelayanan publik. Pengenalan terhadap ombudsman akan dimulai dari sisi historis lahirnya ombudsman, fungsi ombudsman dan mekanisme pengaduan kepada ombudsman.

\section{Pembuatan rencana aksi}

Pembuatan rencana aksi dapat menggambarkan prioritas agenda yang bisa dilakukan masyarakat dalam peningkatan pelayanan publik. Pembuatan model ini tentu didasari atas pemaparan peserta pada tahapan sebelumnya. Berangkat dari pemaparan tersebut maka fasilitator akan memperkenalkan ombudsman. Pengenalan ombudsman difokuskan pada peran dan fungsi dari ombudsman serta mekanisme kerja termasuk bagaimana menggunakan layanan pengaduan pada instansi tersebut. Setelah itu, fasilitator juga akan mensimulasikan kepada peserta dengan memberikan isu persoalan yang selanjutnya akan diminta kepada peserta untuk menindaklanjuti sebagai pengaduan yang masuk kepada ombudsman, mengawal proses pengaduan sampai pada penyelesaian tindak lanjut dari pengaduan mal administrasi tersebut. Adapun khalayak sasaran strategis yang dilibatkan dalam kegiatan pelatihan tentu lebih memprioritaskan peran masyarakat dalam melakukan pengawasan pelayanan publik.

\section{HASIL DAN PEMBAHASAN}

UU Nomor 25 Tahun 2009 tentang Pelayanan Publik telah menguraikan dengan jelas bahwa pelayanan publik adalah kegiatan atau rangkaian kegiatan dalam rangka pemenuhan kebutuhan pelayanan sesuai dengan peraturan perundang-undangan bagi setiap warga negara dan penduduk atas barang, jasa, dan/atau pelayanan administratif yang disediakan oleh penyelenggara pelayanan publik. Definisi tersebut menegaskan bahwa pelayanan publik sebagai segala bentuk jasa pelayanan, baik dalam bentuk barang publik maupun jasa publik menjadi tanggungjawab mutlak pemerintah. Lahirnya UU Nomor 25 Tahun 2009 tentang Pelayanan Publik berangkat dari keinginan untuk mereposisi masyarakat dari inferior menjadi superior, mengingat selama ini pemerintah kerap berlaku dominan. Hal ini bisa dilihat dari citra birokrasi yang terbangun identik dengan peralihan dari meja ke meja, proses yang panjang, berbelit-belit, dan tidak efisien dan tidak efektif. Padahal masyarakat pada dasarnya raja dalam pengurusan layanan.

Oleh karena itu, UU Nomor 25 Tahun 2009 tentang Pelayanan Publik telah membuat standarisasi pelayanan dalam birokrasi yakni: (a) sistem pelayanan yang mengutamakan kepentingan masyarakat, khususnya pengguna jasa; (b) kultur pelayanan dalam organisasi penyelenggara pelayanan, dan (c) sumber daya manusia yang berorientasi pada kepentingan pengguna jasa. Keberadaan UU Nomor 25 Tahun 2009 tentang Pelayanan Publik membawa 
angin segar bagi masyarakat dalam upaya mendapatkan pelayanan yang maksimal dari pemerintah. Dengan adanya tiga standar pelayanan tersebut, setiap aparat pemerintah memiliki definisi yang sama dalam memperlakukan masyarakat sebagai pelanggan. Hal ini sepatutnya juga berlaku bagi aparat pemerintah diwilayah terluar seperti Desa Tuapejat, Kecamatan Sipora Utara, Kabupaten Kepulauan Mentawai.

Desa Tuapejat, Kecamatan Sipora Utara, Kabupaten Kepulauan Mentawai merupakan salah satu Desa yang letaknya terisolir di Provinsi Sumatera Barat. Desa ini terdiri dari sembilan dusun yakni Dusun Jati, Dusun Kampung, Dusun Camp, Dusun Tuapejat, Dusun Karoniet, Dusun Turonia, Dusun Mapaddegat, Dusun Berkat, dan Dusun Pukarayat. Dari sembilan dusun ini, terdapat dua dusun yang terletak di pulau berbeda dan mesti dilalui dengan jalur laut. Adapun total penduduk di Desa Tuapjeat sejumlah 5.109 penduduk dengan rincian 2.588 laki-laki dan 2.521 perempuan (Profil Desa Tuapejat, 2019). Hal ini menandakan jumlah penduduk berdasarkan jumlah gender cukup proporsional.

Dalam penyelenggaraan pemerintahan sendiri, Pemerintah Desa Tuapejat juga memiliki berbagai jenis layanan seperti layananan kependudukan catatan sipil, layanan izin mendirikan bangunan, layanan pajak bumi bangunan, dan lain-lain. Pemerintah desa sebagai ujung tombak layanan sepatutnya mampu menghadirkan pelayanan yang maksimal mengingat kondisi geografis desa yang terisolir dan sangat sulit dijangkau transportasi publik.

Meskipun sudah ada regulasi yang jelas dalam menetapkan standar pelayanan publik, masih ditemukan serangkaian masalah dalam pelaksanaan pelayanan publik dilapangan. Salah satu studi yang dilakukan di Kecamatan Sipora Utara menemukan bahwa masih terdapat perbedaan pemahaman birokrat antara tingkat kepentingan pelayanan yang mesti didapat masyarakat dengan hasil pelayanan yang dirasakan masyarakat (Kurniawan, 2011). Disaat yang bersamaan, masyarakat cenderung pasrah ketika berhadapan dengan birokrat. Hal ini ditandai dengan rendahnya jumlah pengaduan terhadap pelayanan publik yang dilakukan Pemerintah Kabupaten Kepulauan Mentawai. Berdasarkan Laporan Ombudsman tahun 2015 sampai 2017, jumlah laporan pengaduan yang masuk sejumlah satu laporan setiap tahunnya. Salah satu permasalahan yang membuat rendahnya pengaduan ini dikarenakan masyarakat yang tidak begitu mengenal bentuk-bentuk perilaku mal administrasi yang dilakukan aparat pemerintah. Untuk itu, dalam kegiatan pengabdian yang kami lakukan, langkah pertama yang kami lakukan adalah memperkenalkan bentuk-bentuk perilaku mal administrasi yang umum dilakukan aparat pemerintah dalam penyelenggaraan pelayanan publik.

\section{Identifikasi Perilaku Mal Administrasi}

Identifikasi perilaku mal administrasi adalah hal yang mutlak dilakukan ditengah masih lemahnya pengawasan masyarakat dalam penyelenggaraan pelayanan publik terhadap pemerintah daerah. Berdasarkan UU Nomor 37 Tahun 2008 tentang Ombudsman Republik Indonesia, mal administrasi adalah perilaku atau perbuatan melawan hukum, melampaui wewenang, menggunakan wewenang untuk tujuan lain dari yang menjadi tujuan wewenang tersebut, termasuk kelalaian atau pengabaian kewajiban hukum dalam penyelenggaraan pelayanan publik yang dilakukan oleh Penyelenggara Negara dan pemerintahan yang menimbulkan kerugian materiil dan/atau immateriil bagi masyarakat dan orang perseorangan. berikut:

Lebih lanjut, Ombudsman mengklasifikasi beberapa bentuk mal administrasi sebagai
a. Perilaku dan perbuatan melawan hukum
b. Perilaku dan perbuatan melampaui wewenang
c. Menggunakan wewenang untuk tujuan lain dari yang menjadi tujuan wewenang itu
d. Kelalaian
e. Pengabaian kewajiban hukum
f. Dalam penyelenggaraan pelayanan publik
g. Dilakukan oleh Penyelenggara Negara dan pemerintahan
h. Menimbulkan kerugian materiil dan/atau immaterial
i. Bagi masyarakat dan orang perseorangan 
Dari sembilan bentuk mal administrasi diatas, bentuk-bentuk perbuatan mal administrasi yang paling umum terjadi dalam birokrasi adalah penundaan berlarut, penyalahgunaan wewenang, penyimpangan prosedur, pengabaian kewajiban hukum, tidak transparan, kelalaian, diskriminasi, tidak profesional, ketidakjelasan informasi, tindakan sewenang-wenang, ketidakpastian hukum, dan salah pengelolaan (Hendra, 2013). Kesembilan bentuk mal administrasi ini seringkali luput disimak masyarakat karena masyarakat pelayanan birokrasi yang kaku, dan red tape atau diistilahkan penyelenggaraan pelayanan yang berbelit-belit, memakan waktu lama, meski sebenarnya bisa diselesaikan secara singkat telah dianggap menjadi kebiasaan bagi masyarakat.

Dari kegiatan pengabdian yang kami lakukan, peserta pengabdian kurang memiliki sensifitas terhadap perilaku mal administrasi. Budaya yang ada di masyarakat yang berkembang melihat sikap kritis terhadap aparat pemerintah adalah sesuatu yang tabu untuk dilakukan karena pada dasarnya setiap orang adalah keluarga. Hal ini mengingat latar belakang penduduk Desa Tuapejat yang relatif homogen dimana mayoritas adalah penduduk asli dari Kepulauan Mentawai. Yang menarik adalah, perilaku pelayanan aparat pemerintah akan ramah dan cepat ketika penduduk dalam pengurusan pelayanan bisa berbahasa asli Mentawai. Artinya perilaku mal administrasi cenderung bukan didasarkan atas motif koruptif akan tetapi didsasarkan atas pemberian privilege berdasarkan semangat solidaritas sosial dan kekeluargaan. Disaat yang bersamaan, masyarakat juga tidak mengenal mekanisme complaint apabila ditemukan mal administrasi dalam penyelenggaraan pelayanan. Masih kaburnya saluran pengaduan masyarakat terhadap mal administrasi dalam pelayanan di Desa Tua Pejat membuat kegiatan pengabdian ini turut memperkenalkan Ombudsman. Oleh karena itu, langkah kedua dalam kegiatan pengabdian adalah sosialisasi Ombudsman kepada masyarakat.

\section{Pengenalan Ombudsman}

Pasca reformasi, muncul semangat untuk memperkuat peran serta masyarakat dalam penyelenggaraan pemerintahan. Salah satu lembaga yang diberikan berkewenangan untuk mengawasi penyelenggaraan pelayanan publik adalah Ombudsman yang berdiri sejak tahun 2000. Ombudsman menjadi representasi publik untuk melakukan kontrol secara eksternal sekaligus memperkuat pengawasan internal birokrasi yang dilakukan inspektorat. Sinergitas dalam melakukan pengawasan pelayanan publik kerap dikesampingkan selama ini mengingat masih adanya paradigma bagi sebagian aparatur pemerintah yang terkesan tidak ingin dikontrol oleh pihak luar.

Ombudsman adalah lembaga negara yang mempunyai kewenangan mengawasi penyelenggaraan pelayanan publik baik yang diselenggarakan oleh penyelenggara negara dan pemerintahan termasuk yang diselenggarakan oleh Badan Usaha Milik Negara, Badan Usaha Milik Daerah, dan Bada Hukum Milik Negara serta badan swasta atau perseorangan yang diberi tugas menyelenggarakan pelayanan publik tertentu yang sebagian atau seluruh dananya bersumber dari anggaran pendapatan dan belanja negara dan/atau anggaran pendapatan dan belanja daerah. Adapun tujuan pembentukan Ombudsman adalah untuk membantu dan mengembangkan kondisi yang kondusif sesuai dengan amanat dalam Undang-Undang Nomor 37 Tahun 2008 Tentang Ombudsman Republik Indonesia Bab 1 Pasal 1 Ayat 1 melaksanakan pemberantasan korupsi, kolusi, dan nepotisme melalui peran serta masyarakat. Selain itu, Ombudsman diperlukan untuk meningkatkan perlindungan hak-hak masyarakat agar memperoleh pelayanan umum, keadilan, dan kesejahteraan secara lebih baik. Untuk mewujudkan tujuan tersebut, Ombudsman diberi tugas pokok antara lain melakukan langkahlangkah untuk menindaklanjuti laporan atau informasi mengenai terjadinya penyimpangan oleh penyelenggaran Negara dalam melaksanakan tugasnya maupun dalam memberikan pelayanan umum.

Ombudsman tidak sama dengan lembaga-lembaga pengaduan lain karena memiliki keistimewaan tersendiri yang tidak dimiliki oleh lembaga-lembaga pengaduan atau lembaga kontrol yang lain. Apabila sebelum reformasi masyarakat hanya mengenal Yayasan Layanan Konsumen Indonesia sebagai satu-satunya saluran pengaduan publik, saat ini Ombudsman 
relatif dominan mengingat legalitas yang dimiliki Ombudsman selaku lembaga negara yang memiliki kewenangan untuk melakukan investigasi dan memberikan rekomendasi kepada pemerintah untuk memperbaiki kesalahannya yang dilaporkan oleh anggota masyarakat

Dalam menjalankan fungsi dan tugas, Ombudsman memiliki tujuh kewenangan yakni: a) meminta keterangan secara lisan dan/atau tertulis dari Pelapor, Terlapor, atau pihak lain yang terkait mengenai Laporan yang disampaikan kepada Ombudsman; b) memeriksa keputusan, surat-menyurat, atau dokumen lain yang ada pada pelapor ataupun Terlapor untuk mendapatkan kebenaran suatu Laporan; c) meminta klarifikasi dan/atau salinan atau fotokopi dokumen yang diperlukan dari instansi mana pun untuk pemeriksaan Laporan dari instansi Terlapor; d) melakukan pemanggilan terhadap Pelapor, Terlapor, dan pihak lain yang terkait dengan Laporan; e) menyelesaikan laporan melalui mediasi dan konsiliasi atas permintaan para pihak; f) membuat Rekomendasi mengenai penyelesaian Laporan, termasuk Rekomendasi untuk membayar ganti rugi dan/atau rehabilitasi kepada pihak yang dirugikan; g) demi kepentingan umum mengumumkan hasil temuan, kesimpulan, dan Rekomendasi.

Selain wewenang sebagaimana dimaksud pada ayat 1 tersebut, Ombudsman juga berwenang: a) menyampaikan saran kepada Presiden, kepala daerah, atau pimpinan Penyelenggara Negara lainnya guna perbaikan dan penyempurnaan organisasi dan/atau prosedur pelayanan publik; b) menyampaikan saran kepada Dewan Perwakilan Rakyat dan/atau Presiden, Dewan Perwakilan Rakyat Daerah dan/atau kepala daerah agar terhadap undangundang dan peraturan perundangundangan lainnya diadakan perubahan dalam rangka mencegah Maladministrasi.

Yang menarik adalah kewenangan Ombudsman bisa berlaku melekat kepada pemerintah daerah. Berdasarkan Undang-Undang Nomor 32 Tahun 2014 tentang Pemerintahan Daerah, setiap Kepala Daerah wajib melaksanakan rekomendasi Ombudsman. Rekomendasi Ombudsman adalah kesimpulan, pendapat, dan saran yang disusun berdasarkan hasil investigasi ombudsman kepada atasan terlapor untuk dilaksanakan dan/atau ditindaklanjuti dalam rangka peningkatan mutu penyelenggaraan administrasi pemerintahan yang baik. Rekomendasi Ombudsman bukan sekedar usul ataupun saran yang dapat dilaksanakan atau tidak dilaksanakan oleh pihak final dan mengikat. Rekomendasi Ombudsman bersifat final dan mengikat. Kewenangan Ombudsman yang demikian besar dalam melakukan pengawasan penyelenggaraan pelayanan publik merupakan komitmen nyata untuk meningkatkan kualitas layanan.

Dalam struktur yang ada, Ombudsman tidak hanya berada di pusat, tetapi juga ada di setiap provinsi di Indonesia. Hal ini karena pemantauan penyelenggaraan pelayanan tidaklah mungkin hanya dilakukan oleh Ombudsman Republik Indonesia di tingkat Pusat saja. Oleh karena itu disetiap provinsi di Indonesia memiliki perwakilan Ombudsman. Untuk kasus di Provinsi Sumatera Barat sendiri, Ombudsman Republik Indonesia Perwakilan Sumatera Barat lahir sejak 23 November 2012 (Devina, 2018).

Meskipun Ombudsman Republik Indonesia Perwakilan Sumatera Barat telah hadir tujuh tahun lebih, keberadaan Ombudsman Republik Indonesia Perwakilan Sumatera Barat belum dirasakan signifikan bagi masyarakat di Kabupaten Kepulauan Mentawai. Dari kegiatan pengabdian yang dilakukan, keberadaan Ombudsman Republik Indonesia Perwakilan Sumatera Barat belum diketahui tugas dan fungsinya oleh mayoritas lapisan masyarakat. Hal ini dibuktikan dengan minimnya laporan masyarakat terkait permasalahan-permasalahan di bidang pelayanan publik.

Masyarakat menganggap upaya pengaduan mal administrasi Ombudsman Republik Indonesia Perwakilan Sumatera Barat masih tidak efesien dan efektif. Masyarakat beranggapan pengaduan yang dilakukan memakan waktu dan biaya yang besar mengingat jarak tempuh Desa Tupejat ke Kota Padang menggunakan kapal laut berkisar empat sampai dua belas jam dengan biaya 280.000 sampai 500.000 pulang pergi. Disamping itu, masyarakat tidak mengenal saluran alternatif pengaduan lain seperti surat dan aplikasi internet seperti lapor yang langsung terkoneksi dengan Ombudsman Republik Indonesia Perwakilan Sumatera Barat. Padahal saluran pengaduan yang harusnya dibuka oleh Ombudsman Republik Indonesia Perwakilan Sumatera Barat adalah mudah dan terjangkau bagi masyarakat. Ditengah keterbatasan tersebut, 
diperlukan aksi strategis dalam memaksimalkan saluran pengaduan Ombudsman Republik Indonesia Perwakilan Sumatera Barat.

\section{Aksi Strategis}

Selama ini Ombudsman masih berfokus melaksanakan tugas penyelesaian laporan dan pengawasan langsung, sementara masyarakat selaku penerima pelayanan yang terkadang juga menjadi korban dari maladministrasi masih belum seluruhnya paham tentang Ombudsman. Apalagi ada rasa kekhawatiran yang tinggi bagi masyarakat selaku pelapor yang takut dikucilkan dari masyarakat. Oleh karena itu, beberapa rencana aksi yang dilakukan adalah sebagai berikut:

a. Masyarakat harus menyadari bahwa pengaduan yang mereka lakukan bukan dalam rangka menjatuhkan marwah pemerintah. Sebaliknya dengan adanya pengaduan layanan publik memberi nilai positif dalam menghadirkan pelayanan yang maksimal. Oleh karena itu, Ombudsman Republik Indonesia Perwakilan Sumatera Barat sepatutnya menjalankan sosialisasi secara kontinyu kepada masyarakat tentang fungsi dan tugas lembaganya.

b. Mengingat adanya tantangan dalam membangun rasa kritis ditengah masyarakat, diperlukan dukungan dengan membuat simpul-simpul masyarakat didaerah. Keberadaan simpul ini dapat menjadi sarana sosialisasi dan advokasi pengaduan layanan kepada Ombudsman.

c. Ombudsman Republik Indonesia Perwakilan Sumatera Barat perlu membuat langkah strategis dengan mengajak semua elemen masyarakat terlibat aktif bahu membahu dalam upaya meminimalisir tindakan mal administrasi di daerahnya masing-masing. Hal ini bisa dilakukan dengan meningkatkan sistem saluran pengaduan yang mudah dan murah dijangkau masyarakat.

\section{KESIMPULAN}

Keberadaan Ombdusman sangatlah dibutuhkan bagi masyarakat dalam menjalankan fungsi kontrol terhadap penyelenggaraan layanan publik. Oleh karena itu, masyarakat perlu memanfaatkan Ombudsman dengan maksimal agar bisa meminimalisir tindakan mal administrasi sekaligus menindaklanjuti apabila ditemukan mal administrasi didalam birokrasi. Bagi masyarakat di Desa Tuapejat, Kecamatan Sipora Utara, Kabupaten Kepulauan Mentawai, hadirnya Ombudsman seharusnya membawa angin segar mengingat masyarakat hidup di daerah terisolir dan jauh dari akses pelayanan pemerintah. Melalui Ombudsman, masyarakat memiliki harapan yang besar untuk mendapatkan pelayanan yang maksimal.

Dari kegiatan pengabdian yang kami lakukan, keberadaan Ombudsman belum begitu dikenal oleh masyarakat. Hal ini mengingat jangkauan layanan dan sosialisasi Ombudsman Republik Indonesia Perwakilan Sumatera Barat hanya terfokus di daerah-daerah besar. Disamping itu, antusiasme masyarakat dalam melakukan pengaduan mal administrasi juga rendah karena adanya kekhawatiran dikucilkan oleh masyarakat dalam melaporkan suatu instansi.

Untuk meningkatkan fungsi Ombudsman Republik Indonesia Perwakilan Sumatera Barat dalam pengawasan penyelenggaraan pelayanan publik di Desa Tuapejat, Kecamatan Sipora Utara, Kabupaten Kepulauan Mentawai, maka beberapa hal yang bisa dilakukan adalah sebagai berikut:

a. Masyarakat selayaknya mendapatkan sosialisasi secara intensif dan kontinyu dari Ombudsman Republik Indonesia Perwakilan Sumatera Barat terkait fungsi dan tugas Ombudsman secara umum.

b. Ombudsman Republik Indonesia Perwakilan Sumatera Barat sepatutnya perlu membuat program spesifik yang lebih disesuaikan dengan tantangan lingkungan sosial masyarakat seperti Kabupaten Kepulauan Mentawai. Beberapa program spesifik tersebut antara lain membuat simpul-simpul sahabat Ombudsman sehingga streotip terhadap pengkritik pemerintah bisa direduksi perlahan-lahan. 
c. Perlu dilakukan terobosan terkait saluran pengaduan Ombudsman khsususnya melalui jalur internet. Hal ini sangat relevan dalam menekan biaya dan waktu bagi masyarakat mengingat akses mereka ke Kota Padang sangat jauh.

\section{UCAPAN TERIMA KASIH}

Tim pengabdian mengucapkan terima kasih kepada LPPPM Universitas Andalas dan FISIP Universitas Andalas yang telah membantu pendanaan kegiatan pengabdian tahun 2019 ini. Tanpa dukungan dari kedua belah pihak, maka kegiatan ini tidak akan terselenggara dengan maksimal. Kami juga menyampaikan terima kasih kepada Pemerintah Desa Tuapejat, Kecamatan Sipora Utara, Kabupaten Kepulauan Mentawai, yang telah memfasilitasi kegiatan pengabdian. Semoga melalui kegiatan pengabdian ini, keberadaan Ombudsman membawa angin segar bagi peningkatan pelayanan publik ditengah kondisi masyarakat yang hidup di daerah terisolir dan jauh dari akses pelayanan pemerintah.

\section{DAFTAR PUSTAKA}

Fachri, N. 2018. Peran Ombudsman Republik Indonesia Sebagai State Auxiliary Organ Dalam Mengawasi Pelayanan Publik Terhadap Maladministrasi. Skripsi. UIN Syarif Hidayatullah. Jakarta.

Indonesia, Transparency International. 2017. Indeks Persepsi Korupsi Indonesia 2017. Press Release Transparency International Indonesia. Jakarta.

Kurniawan, R. 2012. Analisis Indeks Kepuasan Masyarakat (IKM) Terhadap Pelayanan Publik di Kantor Kecamatan Sipora Utara Kabupaten Kepulauan Mentawai 2011: Implementasi Keputusan Menteri Negara Pemberdayaan Aparatur Negara Nomor Nomor 25 Tahun 2004. Tesis. Magister Ekonomi Pembangunan, Universitas Gadjah Mada. Yogyakarta.

Mulgan, R. Accountability: an ever-expanding concept. Public Administration. 78 (3): 555-573.

Nordholt, H. S., \& Klinken, G. V. (Eds.). 2007) Renegotiating boundaries: Local politics in postSuharto Indonesia. KITLV Press. Leiden.

Devina, S. 2018. Kinerja Ombudsman Republik Indonesia Perwakilan Provinsi Sumatera Barat dalam Mengawasi Penyelenggaraan Pelayanan Publik di Pemko Padang tahun 2015-2017. Skripsi. Universitas Andalas. Padang.

Tidey, S. 2012. Performing the state: everyday practices, corruption and reciprocity in middle Indonesian civil service. Disertasi. Universiteit van Amsterdam. Amsterdam. 